\title{
Nutritional properties of cookies incorporated with mango stone kernel flour
}

\author{
- P.N. Patil ${ }^{1 *}$, S.P. Sonawane ${ }^{1}$ and S.P. Divekar ${ }^{2}$ \\ ${ }^{1}$ Department of Agricultural Process Engineering, College of Agriculture (Dr. BSKKV), Dapoli (M.S.) India \\ ${ }^{2}$ Agricultural Engineering Section, College of Agriculture (Dr. PDKV), Akola (M.S.) India \\ Email: pratikpatilp964@gmail.com; spsonawane1@gmail.com; santosh.divekar75@gmail.com)
}

*Author for Correspondence

Research chronicle : Received : 10.07.2020; Revised : 25.08.2020; Accepted : 05.11.2020

SUMMARY:

Mango is one of the leading processed fruit in the world and there is great demand in the market for the different value-added products from ripe as well as raw mango. Mango processing industries generate a huge quantity of solid waste comprising mainly of peels and stones. After consumption or industrial processing of mangoes, approximately 40 to $60 \%$ waste is generated during processing of mangoes; 12 to $15 \%$ consists of peels and 15 to $20 \%$ of kernels. The mango seed kernel rich in starch, fat, protein and minerals is potentially a good source of nutrients for human and animal feed. The food value of mango seed kernel flour is reported to be nearly equal to that of rice and could be used in foods replacing cereal flours like rice, wheat, corn, etc. Cookies are the most popular bakery items consumed nearly by all levels of society. This is mainly due to its ready-to-eat nature, good nutritional quality, and availability in different varieties and affordable cost. It was found that the moisture, ash, fibre and carbohydrate content increased with increase in proportion of mango stone kernel flour, whereas protein, fat and energy content of cookies decreased with increase in proportion of mango stone kernel flour. The colour analysis of cookies shows that-there is a decrease in $\mathrm{L}^{*}, \mathrm{a}^{*}$ and $b^{*}$ values with increase in proportion of mango stone kernel flour. The result of sensory sensory evaluation shows that the cookies of treatment $\mathrm{T}_{5}(20 \%$ mango stone kernel medium size flour $(0.55$ $\mathrm{mm}$ particle size) and it's incorporation had highest overall acceptability among all treatments. It can be concluded that the incorporation of mango stone kernel flours upto $20 \%$ level with particle size of $0.55 \mathrm{~mm}$ in cookies is recommended which results high fibre cookies as compared to cookies prepared with only refined wheat flour.

KEY WORDS : Nutritional properties, Physical properties, Sensory analysis, Colour analysis, Breaking Strength

How to cite this paper : Patil, P.N., Sonawane, S.P. and Divekar, S.P. (2020). Nutritional properties of cookies incorporated with mango stone kernel flour. Internat. J. Proc. \& Post Harvest Technol., 11(2) : 34-38. DOI: 10. 15740/HAS/IJPPHT/11.2/34-38. Copyright@2020: Hind Agri-Horticultural Society. 